\title{
The Letter of Toledo
}

\section{Gaster Ph.D.}

To cite this article: M. Gaster Ph.D. (1902) The Letter of Toledo, Folklore, 13:2, 115-134, DOI: 10.1080/0015587X.1902.9719673

To link to this article: http://dx.doi.org/10.1080/0015587X.1902.9719673

$$
\text { 曲 Published online: } 06 \text { Feb } 2012 .
$$

Submit your article to this journal ¿

$$
\text { Цll Article views: } 1
$$

Q View related articles $\sqsubset$ 
from St. Briavel's, Gloucestershire," and exhibited an object locally known as "The Gift" in illustration of it [infra, p. 174].

Mr. W. W. Skeat read a paper entitled, "Malay Spiritualism (infra, p. 134), which was illustrated by lantern slides.

The Meeting terminated with votes of thanks to the readers of the several papers.

The following books which had been presented to the Society since the last Meeting were laid on the table, viz. :

The Peabody Museum Papers, vol. ii.. presented by Miss L. Kennedy; The 18 th Annual Report of the Bureau of American Ethnology, edited by J. W. Powell, presented by the Smithsonian Institution; and Folktales from the Indus, by Barlow and McNair, presented by the Authors.

\section{THE LETTER OF TOLEDO.}

BY M, GASTER, PH,D.

(Read at Meeting, 26th February, rgoz.)

IN the year 1184 the world was startled by a letter purporting to come from the sages and astrologers of Toledo. It was sent to Pope Clement. III. and to other men of weight, informing them of the impending doom. The world was to be destroyed in the year i 186 through wind and storms, drought and famine, pestilence and earthquake. The people were advised to forsake their houses and wellbuilt mansions, and to try and find safety in mountains and caverns, to protect themselves against the storms of sand with which the inhabitants of the sea coasts would be visited; notably the towns of the East. The air (continued the letter) will be darkened and poisoned by that fearful wind and in the midst of it a voice or sound will be heard, which will destroy the hearts of men. All towns 
close to the shore will be covered with sand and earth. All this is to happen through the conjunction of all the planets in the sign of the Scales and in the tail of the Dragon, and will take place in the month of September. The sun also will enter into the same conjunction. Such a rare occurrence can only occur by the will of God, in order to be as a wonderful sign of the change to which all mutable things are to be subjected. The premonitory sign will be an eclipse of the sun, immediately before the conjunction of the planets, obscuring the whole body of the sun; and the moon in the opposition will also be totally eclipsed. The sun will appear fiery red and distorted during the eclipse, which, moreover, signifies approaching bloodshed in the neighbourhood of a river in the East and similarly in the West. Doubt and ignorance will seize Jew's and Muhammetans until they forsake their synagogues and "mahumeries." Their sect will then be utterly destroyed by the will of God. Know ye therefore to leave the land so soon as you see the eclipse.

This letter or message was sent in the first place in the name of the astrologers of Toledo, and especially in the name of the Magister Johannes Davidis Hispalensis. There are many variations of the letter, and it has a history of its own, which I intend discussing here. It may appear somewhat remote from the immediate object of our investigations. It has apparently nothing of the folk in it. It is neither a tale nor a custom, nor does it lend itself to any of the metaphysical speculations so much in favour in so many of the more recent researches in the field of folklore. The general inclination seems to be to go to the very remote and necessarily obscure origins of all the manifestations of spiritual folklore, and to attempt thereby to solve the manifold problems which the study of the folk presents. I do not undervalue the merit of these speculations, nor do I intend criticising the work accomplished hitherto; but each of us looks upon these problems in the 
light of his own investigations or predilections, and takes a different path towards the ultimate goal.

Everything with which we come in contact or in which we move is the result of composite forces, and so also is what we call the mind of the people. It is not the simple unfolding in a direct and straight line of any embryonic mental force, but a highly composite product of centuries of development under the most varied influences. The warp and woof of the human mind and of the lore of the people is not woven of one strand or of one colour, it is a multicoloured design of many strands and of many origins. The more we try to unravel this composite design, the more we find that patient following up of each separate thread is the only safe plan, unless we choose to lose ourselves in the labyrinth of metaphysical speculation. We must follow the thread that leads to the skein left at the entrance, and not try to unite ends which are separated in time and history. The historical investigation of each custom, tale, superstition, or charm is the primary condition for the solution of some of the problems of folklore. We shall never solve the riddle of the human heart; and we dare not ignore (as is often done) all the intervening chains and links which bind nations and organizations together, nor content ourselves with finding sufficient ground for new elucidatory theories in a single casual parallel, or even in a number of parallels. Our Society, happily, is not wedded to one single dogmatic teaching, and I contend that in the variety of opinions and views there lies a better prospect of approaching the ultimate truth,than in following one single beaten track. Because of this, I have taken the Letter of Toledo as a typical subject for investigation. It appeared in the middle period of the Christian Era, and started from one of the most famous centres of medixval learning. It will therefore be useful to study the question of this letter upwards and downwards ; to follow its further spread from the twelfth century onwards, and to attempt to trace its origin back to older sources. 
The principal questions which engage our attention are necessarily: in how far has this or any such letter contributed to enrich the stock of popular knowledge and belief? and inversely, how much in it is due to such belief? When we are asked to look upon every item found among the unlettered as a remnant of an old state of mind, independent of, and in some points contrary to, the modern state of the church and of what we call civilisation, it behoves us to make it perfectly clear that no other influences have been at work, and that it cannot be traced to more recent sources of tradition, either by word of mouth or by written literature (which last merely facilitates the spread of the elements of knowledge). One of the greatest delusions, to my mind, is the belief that any nation, nay, any hamlet, has ever lived in absolute isolation from the rest of the world. No such thing has existed, at least in Furope; and I am inclined to extend the possibilities of intercommunication also to other nations and countries. Each kingdom in the East has had a period of great culture and of powerful intercourse between one part of it and another. Whoever has studied, even cursorily, the wayfaring life of the Middle Ages, and the manifold means of carrying tales and news from one place to the other, will not, and in fact cannot, entertain for one moment the theory of isolation. And where is the infuence of the Church? and of the Christian apocryphal literature, which is so full of legendary and miraculous matter, and so well fitted to win the heart of the hearer ? All these sources of popular inspiration must first be laid bare, their influence examined, their changes followed up, and their multifarious combinations described, ere we are in a position to pronounce any specified element in folklore to be an old tradition derived from pre-scientific times, a "relic of an unrecorded past." In this process of sifting, time and patience are required, and however slow the process may be, it is, at any rate, sure and safe. How much can we not learn from studying our own life, our daily experience, especially 
when unmistakable historical evidence fortifies our ubservations! From these we start as from a stable basis venture into more remote speculations upon metaphysical or psychical origins.

To turn now to the Letter. It presents itself as a message sent from the astrologers of Toledo to Pope Clement, informing him that the peculiar combination of the planets in their course prognosticates a serious catastrophe for the inhabited world. Let us note at once two facts. The Letter is sent from Toledo by astrologers. The echo of the Letter is heard almost in every chronicle of the time. Its fame and the dread it produced can be traced throughout Christendom, without limit of time or space. We meet with it in English Chronicles as well as in French, in German, and Italian, with some modifications, which, though slight, are yet of sufficient importance for my thesis.

The profound effect which this letter produced upon the people's imagination proves then, in the first place, how deeply the belief in the influence of the stars had penetrated into human thought in the Middle Ages, much more generally than in older times. An unexpected conjunction of the heavenly bodies was sufficient to terrify both the learned and the unlearned masses. The belief was universal and undisputed. How tempting it would be to discuss here the history of astrology and astrolatry throughout the world, lasting so many centuries! How strongly this belief has ruled over man and has influenced him in many important acts of his life! How many battles have been fought, how many political actions undertaken, under this influence only! And when we speak now of a man being born under a "lucky star," are we not standing under the shadow of the old astrological belief? Are we not still worshipping at the old shrine? One can follow the slow growth of this belief through the old systems of worship, and prove that astro. logy proper-that is, the science of nativities and of the systematic exposition of the influence which each star, by 
itself and in conjunction with others, has upon rnan's career-is an artificial and "scientific" development from more primitive conceptions. Yet it is this highly-developed and artificial belief which was spread and accepted in Europe and still clings to the masses. Shall I mention Zadkiel and Moore, the modern reflex of similar medixval calendars and almanacks with prognostications and nativities? Astrology was imported directly from the East in all its details, and yet we find it in every home and hamlet exercising a far deeper influence upon the unlettered than the prognostications of our modern weather-prophets and the teachings of our astronomers. It is found, I repeat, amongst the masses, and it is contrary to our modern science, yet it is not a "relic of an unrecorded past." We can trace it to a special centre, Toledo-a great university, whither men flocked from all parts of the world desirous of being instructed in the higher branches of knowledge. There was no man who aspired to a high position, or who was eager to slake his thirst for knowledge, who did not repair to that centre of learning and tolerance. Alchemy and astrology were soon added to the curriculum of teaching. Necromancy became by popular etymology nigromancy, the Black Art, and scholars like Michael Scott and Albertus Magnus, who had to pass a course of education at that famous university, soon became identified with nigromancy in the eyes of the people. The teacher at that heathen school could then only be the devil in persona. Among the peculiarVirgil. legends of the Middle Ages, we find one which represents the Devil as the teacher of nigromancy in Toledo, obtaining as the price of his tuition one of twelve scholars who on a certain day had to sit on a flying wheel which turned rapidly, and the one who flew off was quickly snatched up by the teacher as his lawful fee. We can therefore understand the consternation which seized the world when from that centre of mysterious learning such a warning was sent to foretell the impending doom. 
It may be of interest to ask how it came about that a belief of this kind should strike such deep roots in the mind of the nations? Why should people give credence to assertions not easily proved? A legitimate question to put, when once we have reached the starting-point of the belief. The credulity of the masses is no answer. Even credulity presupposes a mental disposition to accept a teaching in which there is no control possible, except it be the chance accomplishment of one or another prediction. When once the belief is established, the mass concludes, by a chain of loose reasoning, that what has proved true in one case may be true in other cases also.

I am not bold enough to deny the possibility of the stars and planets exercising a certain influence upon man and earthly beings. Sun and moon produce the great and stirring movements of the seas known as the tides, and why should they not exercise some similar influence upon the blood, causing it also to ebb and flow? The quick or slow movement of the blood stimulates or neutralises our activity, it makes us sluggish or enthusiastic, and thus determines our action. The whole electric power stored in the earth, of which we now begin to get a faint glimpse, is derived directly trom the sun; the $X$ rays, invisible to us, mould our life profoundly; and wireless telegraphy may be carried on in space with greater effect than we are as yet aware. There may be an elementary basis of rudimentary experience at the root of the vastly-developed science or pseudo-science of astrology. But between the premiss of a possible influence of the heavenly bodies, and the theory and practice of astrology with its systematised interpretation of that influence, yawns the gulf which modern science attempts to bridge. But the people had no clear conception of these truths, or apparent truths. To them sufficed the example of the great, of the kings and the aristocracy; and the authority of the masters stood in place of individual reasoning. Thus, therefore, the Letter spread consternation far and wide, and one of the 
chroniclers, a shrewd olserver of events, connects the stirring of the Third Crusade with the deep emotion produced by these forebodings, which in one version of the Letter are directly connected with the Holy Land and the attacks of Saladin on Jerusalem. No less a personage than Giraldus Cambrensis connects the Crusade with the emotion produced by this Letter. Roger of Wendover, in his Chronicle, under the year 1229 , mentions not only this Letter but three similar letters, the oldest being the one under our immediate consideration. So does Gervasius (to mention only English chroniclers), and so also Benedict of Peterborough. All these ascribe the Letter to Magister Johannes Toletanus.

The period at which the Letter was circulated for the first time was favourable for the publication of such auguries of evil and of catastrophes threatening to destroy the world. The public spirit was then in a state of effervescence, half frightened and half disappointed. The dreaded time of the Second Advent of Christ was expected to take place at the end of the first thousand years; and the expected appearance of the Millennium was one of the factors which had often, especially in ancient times, produced ecclesiastical, social, and political convulsions. The year rooo had been awaited by anxious multitudes, dreading the terrible signs and wonders which were to come upon the world. The year 1000 had just past, and neither had the terrible events come to pass, nor had the enthusiastic expectations been realised. A state of subdued excitement remained. Some of it spent itself in the Crusades, the rest in apocalyptic and mystical literature and in sectarian movements, on which I do not intend entering here. They belong to Church history proper, and are only mentioned here in connection with this astrological Letter.

Man must have something in which to trust, and on which to rely, to strengthen his failing courage and to lift for him, if possible, a corner of the veil that covers the future. Man is always anxious to know that which a wise Providence 
hides from him: "the next day"! Here now stepped in the new science, which professed to be able to foretell not only what would happen on the morrow, but to give to the inquirer an answer as to what would happen to him in the course of his life, and even foretell the length of that life and the way in which he would spend it. Backed by the authority of science and by the magic of the great names of men acquainted with all hidden mysteries and possessed of all the knowledge which canny and uncanny wisdom could grant, the belief was accepted as a key to the future, and the utterances of the astrologers were implicitly believed. It so happened that these forebodings did not come to pass. This is the psychological moment which invests these Letters with a peculiar significance from the point of view of folklore. They shared the fate of all unfulfilled prophecies. The first stage is, that ingenious devices are invented in order to explain the non-fulfilment. The penitent mood of the people, the mercy of God, the intervention of other unforeseen causes obviated the threatened event, and thus the world was saved for the time being. In the case of the Letter of 1186 , no doubt can exist of the truth of the remarkable conjunction of the planets in that particular part of the skies. Professor Grauert, who has studied the later history of this Letter, has been able to ascertain through the instrumentality of the Astronomer-Royal in Berlin that this really happened. Minor occurrences which otherwise would have passed unnoticed were magnified into great heavenly or earthly convulsions. Winds were transformed into raging storms, and slight skirmishes sanguinary battles. In spite of all these devices the world felt that the prophecy had not been fulfilled. They did not hear the crack of doom.

The second stage is the reappearance of the Letter soon afterwards, i.e. about thirty years later. But it has already undergone a slight alteration. It is still ascribed to the astrologers of Toledo, but the name of the eminent man 
who forwards it is now the Cardinal Johannes Toletanus, and the date of the prophecy is now 1229. This Cardinal Johannes has been, if I may say so, rediscovered by Professor Grauert, who published quite recently a monograph on Meister Johannes von Toledo (Munich, I90I), and who studied this letter in extenso in connection with the Cardinal John. To this monograph I must refer for the biblio. graphical notes referring to the Letter. Curious to know who the author of this remarkable writing could be, Professor Grauert has succeeded in unearthing a large number of variants, but he has neither traced its origin nor perceived its bearing on other questions. He is forced to own that the first appearance of the Letter preceded by thirty or more years the life of the Cardinal. This Cardinal John was of English origin and had also studied in Toledo. We are not interested here to follow up his political activity, and to relate his fight against the Emperor in favour of the Pope. His dabbling in alchemy brought down upon him the suspicion of nigromancy and astrology, which went hand in hand in popular imagination. He is credited, therefore, with the authorship of this Letter, in which also a prophecy is inserted about the death of a mighty Emperor in the East, and the appearance of an "Emperor over the whole universe." His contemporary Michael Scott, of the same school, is credited with the authorship of another prophecy in favour of the Emperor Frederic II. against the Pope (about 1244). He is mentioned by Dante as a nigromancer (Inferno, cant. $\mathrm{xx}$., v., I $16 \mathrm{ff}$.). We see now what had happened to the old Letter. In spite of the fact that the planetary conjunction was no longer tenable, it is still repeated as a justification of the events which are foretold; merely the date of the occurrence is altered to suit changed circumstances; and instead of the old and forgotten name, a new one, very much like the old one, also Johannes Toletanus, is substituted. Whilst in the former case it was Johannes David Hispalensis, it is now another pretended Spaniard of the same name, but 
a Cardinal! Roger of Wendover prints this Letter also under the year 1229, and takes it very seriously.

This time also the prophecy is doomed to failure. The Cardinal did not prove more reliable than the older astrologer. But what did it matter? No sooner do new occurrences again cause great excitement than the Letter reappears with almost mathematical regularity. The writer of the fresh Letter does not invent anything new, just as little as did the Apocalyptic writer in ancient times; but he applies old imagery to suit the new requirements. About one hundred years pass away, and in the years 1322-29, during the period of the great commotions in Italy and Central Europe, when great floods sweep the Continent and famine ravages many cities, the Letter is circulated again, still ascribed to Magister Johannes of Toledo. The great storm which raged in Naples in 1343, graphically described by Petrarch, had, according to the latter, been foretold by a bishop living close to Naples who was very much addicted to the study of astrology, who, however, had prophesied an earthquake, and not a storm. Grauert sees in this prophecy the reflex of the same Letter.

The year 1345 was considered by the astrologers as one full of evil portents. In it many conjunctions took place; notably one on the 8th of February, when Saturn, Jupiter, Mars, the Sun, and Mercury were all standing in the same sign. Villani, in his Florentine Chronicle, testifies to the profound impression which these astrological conjunctions produced, and how much they were believed to have caused all the troubles which then visited Italy. The medical faculty of Paris declared these conjunctions to be one of the causes of the plague (the Black Death), and they repeat in their report almost the very words of the Toledo Letter, without mentioning it by name.

The centre of learning had nieanwhile been shifted from Toledo to Paris. The old school of necromancers had disappeared, and new authorities occupied the place as- 
signed to the men of those schools of old. Hence when the Letter reappears it is made to fit the new condition of things. In 1395, about two hundred years after its first appearance, it is found in a Codex at Eichstadt, from which Grauert has reprinted it in full. The main points are absolutely identical. The same events will occur in consequence of the conjunction of the planets in the Cauda Draconis in the month of September,--floods and storms will rage, buildings will be destroyed and valleys submerged. Terrible and long-lasting eclipses of the sun will darken the day, and fiery signs and the eclipse of the moon signify the destruction of nations. Sanguinary battles in the East and in the West, shedding of blood and earthquakes will happen. A mighty emperor will die. Few will survive. The Mohammedans will be seized with doubt and join the Christians. The only safeguard against the impending evils will be to hide in caves inside of rocky mountains provided with food for thirty days. In this prophecy joined the philosophers of Greece, Arabia, Hispania, and Francia. It was signed by twenty-one Magisters in Paris on the Ist of April. Professor Grauert asks whether the date of the "Ist of April" does not point to the fact that this Letter may be the work of a way who intended to play a practical joke. I do not think so. The people at that time were not much given to practical joking, and the year 1395 was anything but favourable for it. The world was too much distraught by internal strife and foreign wars, and minds were under the strong influence of mystical and apocalyptic literature.

I will pass over the other parallels tound in the course of the fifteenth century, and will mention only one more variant of this letter, dated 1480 , and published by Grauert from MSS. in the Florentine Library. This last version is of the utmost importance, for it helps us to recognise the elements out of which it had grown. It is not, as Professor Grauert suggests, a reflex of the Toledo Letter. 
mixed up with other elements gathered from different sources. Before I give an abstract of this somewhat lengthy document, it will be of interest to notice that a German translation of the Letter exists of the same year, and if my memory does not entirely deceive me, I remember having seen a variant of it in an English chapbook. I have not been able to trace it now, but hope with the assistance of others to find it yet. This shows how long the Letter has been able to exist. In its latest form it has lost its name and does not mention any authority, but the principal features, the storm and the eclipse of the sun, the death of an emperor, and the terrible phenomena in heaven and upon earth, are faithfully reproduced. It is still an astrological message, though much toned down as far as the astrology is concerned. It is now a simple chapbook.

But to return to the Florentine variant. No Johannes and no David are any longer mentioned. Neither is Toledo or Paris referred to. Similarly, little is heard of philosophers and astrologers. The letter comes as a message from a pious hermit from behind Mount Sinai, and also from a certain Rasis of Antiochia, who have both got their information from Arabic writings. The chief points are as follows: "Great tribulations will begin with the year 1447 and will continue until I 510 , growing steadily all the while. The land of the Christians will be filled with more anguish and pain than can be described. Wars and bloodshed in the East and West, famine, plague, dearth, and death. The Pope will cry in vain asking the kings to make war in the Holy Land. The kingdom of the Franks (Francorum) will be destroyed through their ignorance. Heresies will terrify the world, and not even three Cardinals will be left in Rome, the Pope himself fleeing from the city. Many clerics will deny their faith, and the altars of Paul and Peter will be defiled. Earthquakes will destroy many towris. The planets will produce much poison among the nations, and the air will be filled with exhalations which will cause human bodies to shrivel up. 
Storms will raise the sand in sandy places and will cover men until they be suffocated. A total eclipse of the sun will envelop the whole world in darkness, and the moon will appear ruddy and dark. All the nations will be seized with ignorance and doubt. The Saracen will relinquish his synagogues and "mahummerries." A mighty emperor will die seven months after the eclipse. The sea will overflow its border, and the winds will blow so strongly that no ship will be able to withstand their force. Trees will be uprooted and houses overthrown. The only way to escape will be to go into the open plain and to build houses of wooden beams, covering them with earth, and taking care to be far away from trees, so that they should not fall upon these habitations and crush them. Daniel had already foreseen the coming forth of the Ishmaelites at the end of the sixth sign of the centuries (sic), who would cause widespread misery and confusion. Many Christian nations would be delivered into their hands, because of their sins. The Ishmaelites will conquer and subdue Greece, Gallia, Hispania, Germania, Aquitania, the Islands of the Sea, even Jerusalem and the Land of Promise. (The cruelties to be perpetrated by the Ishmaelites when they break forth from the desert are then minutely described.) Their power will be the greatest in Spain, and they will go about decked in silver and gold and covered with precious stones. The elect of the Christians will then appear, and will show by their sufferings and martyrdom their steadfast adherence to their faith. God will then remember His promise and free them from the yoke of the Saracens. A Roman emperor will then be raised anew, who will smite the Ishmaelites with the edge of the sword and drive them away. In Persia, Egypt, and Spain he will visit on them their iniquities sevenfold, and peace will reign in the lands of the Christians. Then will appear the two nations Gog and Magog, and divide Asia among themselves. The frightened inhabitants will hide in the crevices of the mountains and in caverns, 
for the heathen eat also human flesh, and no one will be able to contend with them. The Roman emperor will then besiege Jerusalem for seven years, at the end of which the Son of Perdition will be born. Antichrist will be born in Babylon, brought up in "Denceaym (Grauert thinks Corozaim) Bethsaida," and will rule in Cafernaum. As soon as he makes his appearance the Roman emperor will go to Golgotha, and, taking off his crown, will place it upon the spot of the Crucifixion. He will pray and give up his soul in prayer. In ${ }_{15} 16$ Antichrist will proclaim himself king, and will do marvellous things and perform wonders and signs almost as God; fire will he cause to fall from heaven, the demons will obey him, the hidden treasures will be revealed to him. The sun will be darkened, and the moon will appear like blood, and he will deceive many. He will then kill two servants of Christ and leave their corpses unburied for three days, after which they will be quickened into life and ascend to heaven. But in the year I 520 Christ will kill Antichrist with the breath of his mouth on Mount Olivet, and the archangel Michael will destroy the heathen nations of Gog and Magog and burn them with fire in the eyes of all the nations, so that they be consumed. In $154^{\circ}$ there will be one flock and one shepherd.

Thus far the abstract of this curious Letter. Its full significance can only be gauged if we remember the time of its appearance. The Middle Ages are drawing to a close. The Reformation is beginning in the Church. Dissatisfaction is rife everywhere, and the Church of Rome is beginning to be identified with the Antichrist of the old Christian tradition. The approach of the Millennium is taught by many, and preparations are made for the Second Advent of Christ. I am leaving the dogmatic questions severely alone, and I point merely to such developments of Millennary hopes and inspirations as we meet with among the Anabaptists and the Rosicrucians; not to speak of many other similar movements elsewhere. Many sects with similar views appear voL. XIII. 
in England in the 17 th century; notably through the efforts of Joseph Mede, and more so through Jane Leade, who established the well-known Philadelphic Society, a society of the elect to await the coming of the "Bridegroom." Dates are fixed for the reappearance of Christ; and, as a corollary, for that of Antichrist, in spite of the fact that he was identified with the Pope and the Church of Rome. This and similar letters were implicitly believed in, and taken to convey oracles and prophecies which confirmed the people in their expectation of impending events. The period is saturated with mystical and apocalyptical literature.

It is idle to assume that such writings have remained outside the sphere of the "people;" on the contrary, if anything, they were and are potent factors in moulding the spiritual life of the masses, for their influence has been deep and lasting. How deeply it has sunk into the mind of the people can easily be seen if we examine the popular belief in such premonitory Letters and in astrological predictions, and co-ordinate popular notions with the principles that are presupposed, or are expressly mentioned, in these mystical messages.

They were eagerly taken up and easily believed, because they chimed in with a large mass of similar tradition that had filtered down from ancient times. The Letter of Toledo became again merged in what I conceive to be the main stream of apocalyptical tradition, which permeated the ancient Christian world. It had formed for a short time a branch of the river. The non-fulfilment of the Millennium at the end of the year rooo, which had been so eagerly and faithfully awaited since the days of St. Augustine (who gave that interpretation to the classical passages in the Gospels and in the Apocalypse of St.John), had somewhat disconcerted the faithful. Now there arose another source of terror, based upon the new science of astrology. The people in moments of extreme fear remember the old 
dark sayings of the past; they turn to the old literature, discarded for a time. What was then more natural than to turn to the old formula of the Antichrist, with the signs and portents which were to announce the dread event to the terrified masses? The old imagery is revived funder different circumstances, and thus a letter from the astrologers of Toledo is the form in which it now appears. The setting is somewhat different but the substance is the same. The old Antichrist legend had meanwhile become thoroughly assimilated. The nations of the West knew it. It was known to the old Eddaic writer of the Voluspä, as has been shown by recent investigations. The Ragnarök and the $M$ uspilli are evidently derived directly from the Antichrist Saga. The Doomsday of the so-called Saxon mythology is the result of the Christian apocryphal teaching. The end of the world is introduced for the first time to the heathen nations. The Christian element is presented in a mythological form; only the names are altered, not the substance. Instead of a mythical, there is an astrological background, and at once we have the letter evolved out of the Antichrist legend. Suppose for one moment that the chain of evidence had broken, and that we found ourselves face to face with modern chapbooks and astrological prognostications, so absolutely identical in form with the Völuspä, what would be more natural that to assume that these two belong to one and the same old mythical European tradition, and that the chapbook must be the remnant of the old form of belief, so ci utrary to the modern notions of astronomy and of a "Dcomsday"?

For this Antichrist legend, with the signs and wonders in it, is of a very complex origin. It is the growth of centuries, during which many of the features with which we are familiar in its European shape have been slowly added. Bousset and others have described the history of this growth, and have attempted to trace the various elements which enriched it to their primary sourrer. Phrasen from 
the Sibylline Oracles as well as well as from the Bible and the Gospels, peculiar interpretations of the classical passage in the Revelation, crystallised slowly round a central idea, whıch may be even older than Christianity. Gunkel sees in it the reflex of old Babylonian myths, of the fight of the Dragon with God. But we are not now concerned with eschatological origins. The problem with which we are dealing is the question of the more recent growth and the spread of the developed form. It is therefore not devoid of interest to point out that Bede in the eighth century, one of the oldest chroniclers of the fifteen signs of the Antichrist, and of the Crack of Doom, presents a very complete system and theory of Antichrist. It is this very composite form, the result of hundreds of years of development, with which both the Northern writers and the authors of mediaval apocalypses were acquainted. They knew, not the single scattered elements, but the complete legend. They give the same imagery in almost the same sequence, as we find in the Letter of Toledo, both in its earliest and latest versions. In all these versions, as in the Antichrist Saga, the scattered elements are focussed into one sustained narrative. Each of the parallels and each single item can be traced to the writings of the Fathers of the Church. The different signs existed separately, and were only at a later period added one after another to the central figure of Antichrist. It is not necessary to quote the parallels to that passage in the Florentine version which gives a description of Antichrist, his rule over the world, the appearance of Gog and Magog, the slaying of God's two witnesses, for they speak for themselves and unmistakably betray their origin. Of greater interest it is to find the parallels to such portions in the Letter of Toledo in 1186 as are connected with Doomsday. Let us take the hurricane and storm. We find them in Sibyll, viii., 203. "And the sun shall appear darkling by night, and the stars quit the sky, and with great fury a hurricane shall lay waste the 
earth, and (then) shall be the resurrection of the dead." (Bousset, 247). Lactantius quotes another Sibyl saying: "A trumpet shall send forth from heaven a sound of much wailing" (ib. 248). The conversion of the Jews and Saracens, a constant figure in the Letter, is clearly taken from a fairly developed form of the Antichrist legend (v. Bousset, p. 2I4, ff.). In the Letter the conversion has no meaning whatever, for that is intended as a warning to the people to beware of a catastrophe which is to overtake all without distinction of race or creed; but by tracing the incident to its source we see the true meaning of the reference.

To sum up. The legend of Antichrist, starting from one centre and from one spiritual medium, gathers strength and volume before it reaches Europe, when it is quickly taken up by the imaginative portion of the population. After a time it is thoroughly assimilated. The idea of the End of Days, which may or may not have previously existed among the European nations, obtains a definite shape under its influence. Other circumstances drive these newly-acquired conceptions into the background. Unfulfilled prophecies, expectations which have turned out vain, contribute to the partial obscuring of the legend in its original and complex form. Under other circumstances one part of it, however, is revived under a somewhat altered shape. The limitless dark future is replaced by immediate fixed dates. Instead of the end of the whole world, a partial impending destruction is described. Credulity is revived, spiritual forces are again at work, astrology joins hands with mysticism and aporalyptic visions, and thus secures a new lease of life for the old set of hopes and fears. The legend is circulated under changed names, adapted to new situations. Another political and religious change brings the old legend to life again, and gives it another interpretation, as happened to the Antichrist legend at the time of the Reformation. The intermediate form is then merged again into the older 
and truer one, and both contribute to enrich popular fancy and poetry.

Only a careful first-hand investigation of documentary evidence will succed in sifting the so-called ancient remnants existing in the minds of the people, and in determining whether they are to be looked upon as such "relics of an unrecorded past " or as fragments of recent origin. I have tried here to join link to link in the chain of tradition in order to show how deep the influence of this form of the Antichrist legend has been, and how far-reaching in its results upon the religious and political development of the nations of Europe during the last thousand years, in the course of which the Letter of Toledo has played an important part. Other investigations will doubtless show how much it has enriched the people's knowledge and has contributed to bring about that state of mind which strikes us as archaic and " folkloric."

\section{GASTER.}

\section{MALAY SPIRITUALISM.}

HY WALTER SKEAT, M.A.

(Read at Meeting, 26th March, 1902.)

WHEN I recently had the honour of being invited by the Council to read a paper before this Society, I had nothing ready which seemed suitable for the purpose. It appeared to me, however, that it would be a useful piece of work to bring together in one paper the main facts concerning the spiritualistic beliefs of the Peninsular Malays, with special reference to motor-automatisms of the type of the DiviningRod, where the motions of an inert object in contact with a human being may be regarded as externalisations of subconscious knowledge. Out of this idea the present paper 